MUĞLA Mugla Journal of Science and Technology

\title{
PER3 VNTR GENOTYPES MAY PREDICT OVERALL SURVIVAL IN BLADDER CANCER PATIENTS IN THE TURKISH POPULATION
}

\author{
*Zeynep YEĞìN, Medical Laboratory Techniques Program, Vocational School of Health Services, Sinop University, Sinop, Turkey, \\ zyegin@sinop.edu.tr \\ (iD) https://orcid.org/ 0000-0003-4637-0253) \\ Filiz ÖZEN, Department of Medical Genetics, Goztepe Training and Research Hospital, Istanbul Medeniyet University, Istanbul, \\ Turkey, dr.fozen@hotmail.com \\ (iD) https://orcid.org/0000-0001-9187-5387)
}

Yasin ALTINIȘIK, Department of Statistics, Faculty of Science and Arts, Sinop University, Sinop, Turkey, yasinn_alt@hotmail.com

(iD) https://orcid.org/0000-0001-9375-2276)

İbrahim Halil YILDIRIM, Department of Genetics, Faculty of Veterinary, Dicle University, Diyarbakır, Turkey, ihyildirim@gmail.com

(iD) https://orcid.org/ 0000-0001-5518-5004)

Asıf YILDIRIM, Department of Urology, Goztepe Training and Research Hospital, Istanbul Medeniyet University, Istanbul, Turkey, asifyildirim@yahoo.com

(iD) https://orcid.org/0000-0002-3386-971X)

Received: 26.02.2020, Accepted: 04.06.2020

*Corresponding author

Research Article

DOI: $10.22531 /$ muglajsci.695085

\begin{abstract}
Circadian genes were proven to play significant roles in tumor development and progression via coordinating various cellular processes. Though circadian rhythm disturbances both on the level of expression and genetic variant analysis have been associated with increased risk for many cancer types, none has investigated the potential effect of PER3 VNTR in bladder tumorigenesis yet. In this study, we aimed to assess PER3 VNTR's effect in terms of creating susceptibility to bladder carcinoma formation. Our second target was to enlighten the possible associations between PER3 genotypes and clinicopathological correlations in bladder carcinoma cohort and thus evaluate outcomes in bladder carcinoma prognosis. In this case-control study, 116 patients and 120 healthy controls were recruited. DNA was isolated from peripheral blood using the standard salting-out procedure and PER3 VNTR variants (ins/del polymorphism) were determined with PCR technique to distinguish the 5-repeats allele (401 bp) from the 4-repeats allele (347 bp). Though this exploratory analysis did not provide evidence supporting the role of PER3 VNTR in the onset of bladder carcinoma, it enabled us to make a risk assessment for the prognosis of bladder carcinoma patients. The survival times of patients decreased in the patient group (progression and cystectomy positive) for PER3 $4 / 4$ genotype and (recurrence, progression and cystectomy positive) for PER3 4/5 genotype. Results presented in this study are highly recommended to be investigated and validated in larger samples in different populations and ethnicities to generalize potential clinical utility.
\end{abstract}

Keywords: Bladder carcinoma, circadian genes, PER3, VNTR, survival

\section{PER3 VNTR GENOTIPLERİ, TÜRKIYY POPÜLASYONUNDA MESANE KANSERİ HASTALARINDA GENEL SAĞKALIMI TAHMİN EDEBİLİR}

\begin{abstract}
Özet
Sirkadiyen genlerin, çeșitli hücresel süreçleri koordine ederek tümör gelişimi ve ilerlemesinde önemli roller oynadiğı kanıtlanmıştır. Her ne kadar hem ekspresyon seviyesi hem de genetik varyant analizi üzerindeki sirkadiyen ritim bozuklukları birçok kanser tipi için artmış riskle ilişskili olsa da, mesane tümörü olușumunda PER3 VNTR'nin potansiyel etkisi henüz araștırılmamıștır. Bu çalıșmada PER3 VNTR'nin mesane karsinomu oluşumuna duyarlılık yaratma açısından etkisini değerlendirmeyi amaçladık. Íkinci hedefimiz mesane karsinomu kohortunda PER3 genotipleri ile klinikopatolojik korelasyonlar arasındaki olası ilişkileri aydınlatmak ve böylece mesane karsinomu prognozundaki sonuçları değerlendirmektir. Bu vaka-kontrol çalışmasına 116 hasta ve 120 sağllklı kontrol dahil edildi. DNA, standart tuzla çöktürme prosedürü kullanılarak periferik kandan izole edildi ve 5-tekrarlı alleli (401 bp) 4-tekrarlı allelden (347 bp) ayırt etmek için PCR tekniği ile PER3 VNTR varyantları (ins/del polimorfizm) belirlendi. Bu araștırmanın sonuçlarının analizi, mesane karsinomunun başlangıcında PER3 VNTR'nin rolünü destekleyen kanıt sağlamamasına rağmen, mesane kanseri hastalarının prognozu için bir risk değerlendirmesi yapmamızı sağladı. Hastaların sağkalım süreleri hasta
\end{abstract}


grubunda PER3 4/4 genotipi (progresyon ve sistektomi pozitif) ve PER3 4/5 genotipi (rekürens, progresyon ve sistektomi pozitif) için azalmıştır. Bu çalışmadan çılkan sonuçlar, potansiyel klinik faydayı genelleștirmek için farklı popülasyonlarda ve etnik kökenlerde, daha büyük örneklerde araștırılması ve doğrulanması gerektiğini belirgin șekilde göstermektedir. Anahtar kelimeler: Mesane kanseri, sirkadiyen genler, PER3, VNTR, sağkalım

\section{Cite}

Yeğin, Z., Özen, F., Altınışık, Y., Yıldırım, İ. H., Yıldırım, A., (2020). “Per3 vntr genotypes may predict overall survival in bladder cancer patients in the turkish population", Mugla Journal of Science and Technology, 6(1), 120-135.

\section{Introduction}

The rhythmic oscillation periods changing in 24 hours are called circadian (from the Latin phrase circa diem). These day-night changes are controlled by autonomous biological pacemakers called circadian clocks. The circadian clock has a master oscillator located in the neurons of suprachiasmatic nuclei in the anterior hypothalamus of the brain and master circadian oscillator synchronizes peripheral tissues of mammals [1-4]. Circadian clock gene family has nine important members including circadian locomotor output cycle kaput (CLOCK), brain and muscle Arnt-like protein-1 (BMAL1), Period-1 (Per1), Period-2 (Per2), Period-3 (Per3), Cryptochrome-1 (Cry1), Cryptochrome-2 (Cry2), Caseinkinase-1 (CK1) and Timeless (TIM) [5-6]. Circadian genes were proven to be highly significant in medical field. As well as their major roles in neurological and mood disorders, circadian genes have also gained attention for cancer studies and altered patterns of circadian genes have been shown in various types of cancers as explained in detail in discussion part.

Per family genes are considered as tumor suppressor genes and they can manage the inhibition of tumor formation through two main mechanisms; either with combination with tumor suppressor p53 or with promotion of the repair of the cells affected by radiation-induced DNA damage [7]. PER3 variable number tandem repeat (VNTR, rs57875989) length polymorphism has either 4- or 5-copies of a 54-bp sequence encoding 18 amino acids. The 5-repeat PER3 allele has already been shown to be associated with a penetrant phenotype for morning circadian preference [8], depressive symptoms and an earlier onset of bipolar disorder [9-10]. Though PER3 VNTR has globally begun to be an attractive target in mood disorders, there are so few reports analyzing its possible effects in tumorigenesis.

In the study, we aimed to investigate the possible effect of PER3 VNTR in the formation of bladder tumors in a Turkish cohort. Moreover, we also targeted to search whether any PER3 genotype could be associated with clinicopathologic correlations in bladder carcinoma cohort.

\section{Material-Methods}

\subsection{Participants}

Unrelated 120 healthy controls and 116 patients were recruited in this case-control study. Patients with transitional cell carcinoma of the bladder were recruited from the Department of Urology, Istanbul Medeniyet University, Turkey and none of the patients had an accompanying tumor history. Healthy controls included in the study were randomly selected from a pool of healthy volunteers from the university. The study was conducted in compliance with the Declaration of Helsinki and was approved by the Local Ethics Committee of Istanbul Medeniyet University (Approval number: 2020/0031).

\subsection{Genotyping}

DNA was isolated from peripheral blood using standard salting-out procedure [11]. PER3 VNTR variants were determined with PCR technique with previously described primer sequences [9]. PER3 PCR reaction was carried out in a $25 \mu \mathrm{l}$ total volume containing $\sim 100 \mathrm{ng}$ genomic DNA, $0.5 \mu \mathrm{M}$ of each primer, $0.2 \mathrm{mM}$ of each dNTP, $2 \mathrm{mM} \mathrm{MgCl} 2,1 \mathrm{x}$ Taq polymerase buffer, and $1.5 \mathrm{U}$ Taq polymerase (Thermo Fisher Scientific, Inc.). Thermal cycler condition was as follows: 35 cycles of denaturation for $40 \mathrm{sec}$ at $94^{\circ} \mathrm{C}$, annealing for $45 \mathrm{sec}$ at $55^{\circ} \mathrm{C}$ and extension for $45 \mathrm{sec}$ at $70^{\circ} \mathrm{C}$. A predenaturation step for $6 \mathrm{~min}$ at $94^{\circ} \mathrm{C}$ and a final extension step for $12 \mathrm{~min}$ at $70^{\circ} \mathrm{C}$ were included. Post PCR products were loaded on 2.5\% ultra-pure agarose gel, stained with ethidium bromide, electrophoresed and analyzed with gel documentation system (SYNGENE Ingenius 3, England) to enable to the analysis of ins/del polymorphism to distinguish the 5-repeats allele (401 bp) from the 4-repeats allele (347 bp). Heterozygotes $(4 / 5)$ resulted with both bands.

\subsection{Statistical analysis}

Statistical analysis was done using R3.6.1 software. The statistical level of significance was defined as $\mathrm{p}<0.05$. The relationship between bladder cancer risk and PER3 VNTR with 4/4, 4/5 and 5/5 genotypes was evaluated using Pearson's Chi-squared test with Yates' continuity correction and Fisher's exact test by means of using the odds ratio (OR) and confidence intervals (95\%). We also studied the probability of death by means of demographic and clinicopathologic characteristics of patients for PER3 VNTR with the 4/4, 4/5 and 5/5 genotypes. Finally, we performed a survival analysis to investigate the survival probabilities of patients over a period of time.

\section{Results and Discussion}

We investigated whether PER3 VNTR was a potential cause for bladder carcinogenesis. The study contained 120 healthy controls and 116 bladder cancer patients. The controls and patients were divided into three 
groups based on their genotypes: $1=4 / 4$ genotype, $2=$ $4 / 5$ genotype and $3=5 / 5$ genotype. The outcome was the status of a person ( $0=$ alive and $1=$ exitus $)$. The patients were inspected in terms of their demographic and clinicopathologic characteristics. The categorical variables representing the demographic characteristics of patients were age $(1=<60$ years and $2=\geq 60$ years), gender ( 1 = male, 2 = female) and smoking status $(0=$ No and 1 = Yes). Similarly, the categorical variables representing the clinicopathologic characteristics of patients were tumor type $(1=$ pTa/LMPUN and $2=$ pT1/pT2), grade ( $1=$ Low and $2=$ High), associated CIS $(0=$ No and $1=$ Yes), tumor size $(1=<3 \mathrm{~cm}$ and $2=\geq 3$ $\mathrm{cm})$, tumor number $(1=$ Single and $2=$ Multiple $)$, recurrence $(0=$ No and $1=$ Yes $)$, progression $(0=$ No and $1=$ Yes $)$ and radical cystectomy $(0=$ No and $1=$ Yes). Table 1 displays the number of observations (n) and percentages $(\%)$ of the patients with respect to their demographic and clinicopathologic characteristics for PER3 VNTR with the 4/4, 4/5 and 5/5 genotypes (and all patients together). Figure 1 displays two box plots in which we compared the number of observations between the levels of the groups (i.e., healthy controls and bladder cancer patients) and the levels of the types of genotypes (i.e., the genotypes $4 / 4,4 / 5$ and 5/5). In Table 2, we investigated the relationship between PER3 VNTR and bladder cancer risk using Pearson's Chisquared test with Yates' continuity correction and Fisher's exact test in terms of odds ratios (ORs) and their confidence intervals. We compared the patients against the controls to evaluate whether the types of genotypes (and allele frequencies) for PER3 VNTR were related to the risk of carcinoma by considering that the reference category contains the people with the $4 / 4$ genotype (and 4-repeats allele frequency). The results in this table showed that the genotypes $4 / 5$ and 5/5 do not exert much influence on the risk of bladder cancer when the people with the 4/4 genotype were the reference category $(\chi 2=2.601, p=0.107 ; \chi 2=0.000, p$ $=1.000$ ). Similarly, 5-repeats allele frequency did not have a significant impact on the risk of carcinoma when the reference category was 4-repeats allele frequency $(\chi 2=0.222, p=0.638)$. The results of Fisher's exact test using the odds ratios and their confidence intervals supported the conclusion above. Here, the odds ratio represents the relationship between the risk of bladder carcinoma and the type of genotype (or the allele frequency) for which the value of one indicating the lack of association between them. For example, the confidence interval between the lower bound 0.908 and the upper bound 2.971 contains the value of one. Thus, $\mathrm{OR}=1.637$ indicates that there is not a significant association between the levels of the groups (i.e., controls and patients) and the levels of the type of genotypes (i.e., the genotypes $4 / 4$ and 4/5) in terms of the risk of carcinoma. Stated otherwise, people with the 4/4 genotype had 1.637 times higher bladder carcinoma risk than people with the $4 / 5$ genotype, however, this difference was not statistically significant. Similarly, OR
$=1.114$ indicates that having 5 -repeats allele frequency more than 4-repeats allele frequency does not increase the risk of bladder carcinoma. There is no direct association between the levels of the outcome the status of patients (i.e., alive and exitus) and PER3 VNTR $\left(\chi^{2}=\right.$ 0.057, $\mathrm{p}=0.972$ ). Table 3 shows the association between the status of patients and the levels of the demographic and clinicopathologic variables for PER3 VNTR with the 4/4, 4/5 and 5/5 genotypes (and all patients together). For PER3 VNTR with $4 / 4$ genotype, the clinicopathologic variables recurrence $(\chi 2=5.457$; $p$ $=0.019)$, progression $(\chi 2=15.717 ; \mathrm{p}=0.000)$ and radical cystectomy $(\chi 2=4.471 ; \mathrm{p}=0.034)$ have significant effects on the status of patients. Similarly, recurrence $(\chi 2=6.681 ; p=0.010)$, progression $(\chi 2=$ $21.120 ; \mathrm{p}=0.000)$ and radical cystectomy $(\chi 2=9.725 ; \mathrm{p}$ $=0.002$ ) exert significant effects on the status of patients for PER3 VNTR with 4/5 genotype. These variables do not have significant effects on the status of patients for PER3 VNTR with 5/5 genotype. Figure 2 displays the association between the status of patients and the levels of these three variables. This figure shows that the probability of death increases as the patients develop recurrence and tumor(s) have progression in case of the radical cystectomy for PER3 VNTR with the genotypes $4 / 4$ and 4/5, while this association does not apply to PER3 VNTR with the genotype 5/5.

We also performed a survival analysis to inspect the survival probabilities of patients. The Kaplan-Meier method is applied to create survival curves and the log rank test is used to test whether these curves are statistically different from each other. We first analyze whether PER3 VNTR alone exerts a direct influence on the survival probabilities of patients. Figure 3 shows three survival curves each of which indicates one level of PER3 VNTR. The corresponding log rank test indicates that PER3 VNTR does not have a direct impact on the overall survival of patients $(\chi 2=0.148$; $\mathrm{p}=$ 0.928). Table 4 displays the log rank test results for the relationship between the survival times of patients and the levels of demographic and clinicopathologic variables for PER3 VNTR with the 4/4, 4/5 and 5/5 genotypes (and all patients together). For PER3 VNTR with 4/4 genotype, progression $(\chi 2=5.271 ; \mathrm{p}=0.022)$ and radical cystectomy $(\chi 2=7.658 ; p=0.006)$ have significant impacts on the survival times of patients, but this association is not apparent for the variable recurrence $(\chi 2=0.167 ; p=0.280)$. The results for PER3 VNTR with $4 / 5$ and 5/5 genotypes are in line with the results presented in Table 3. Figures 4, 5 and 6 display the corresponding survival curves of the levels of recurrence, progression and radical cystectomy for PER3 VNTR with 4/4, 4/5 and 5/5 genotypes (and all patients together), respectively. Note that Figure 6 does not contain the survival curves showing the association between the levels of variable radical cystectomy and the survival times of patients for PER3 VNTR with 5/5 genotype, since there is no patient in the data who is under radical cystectomy with $5 / 5$ genotype. 
Altered expression patterns of circadian gene family members have been shown in a variety of tumor studies proving that there is a strong association between disruption of circadian rhythm and occurrence of some cancer types. That is not surprising considering the fact that approximately $5-15 \%$ of genome-wide mRNA expression is circadian rhythmic and driven by clock genes [3]. Moreover, it has already been demonstrated that there is an interaction between circadian genes and tumor suppression and apoptosis regulation; for instance, c-Myc is controlled by Per2 through the activity of Bmal1/Clock heterodimers [12]. In comparison to the adjacent non-cancerous cells, differential expression patterns of three PER genes (PER1, PER2, PER3) were shown in breast tumor cells [1]. Compared with the patterns of healthy individuals, expression levels of PER1, PER2, PER3, CRY1, CRY2, and BMAL1 were markedly impaired in both chronic phase and blastic crisis of chronic myeloid leukemia cases and downregulated PER3 expression was shown to be associated with the inactivation of PER3 by methylation [13]. PER1, PER2, PER3, CRY2, and TIM expression levels decreased in hepatocellular carcinomas and PER3 downregulation level was as high as $78.3 \%$ compared to the paired noncancerous tissues and correlated with the tumor size $(>3 \mathrm{~cm})$ [2]. Expression levels of a number of circadian genes were evaluated in colorectal cancer patients and in the tumor tissues of the patients, decreased expression patterns were shown for ARNTL1, PER1, PER2, PER3, and CRY2, compared to the matched healthy mucosa [3]. Compared to the adjacent normal mucosas, elevated expressions of Clock and CK1E and decreased expression levels of Per1 and Per3 were shown in colorectal cancer [14]. In the study of Wang et al. [15], a 2.8-fold decrease in PER3 mRNA levels of colon cancerous tissues was reported and PER3 expression was also correlated to some clinicopathologic variables such as tumor location, differentiation, stage and survival. Statistically significant decreased expression levels of Per1, Per2, Per3, Cry1, Cry2, Tipin, Tim, CK1E, Bmal-ARNTL, and Clock were reported in pancreatic cancer [16]. Compared with adjacent normal lung tissues, decreased immunohistochemical expression levels of Per1, Per2, and Per3 were shown in lung cancer samples and these decreased patterns were associated with clinicopathological factors such as poor differentiation, tumor status, stage, and lymph node metastasis [5]. Downregulated mRNA expression patterns of PER1, PER2, PER3, CRY1, CRY2, BMAL1, and TIM were reported in acute leukemia and PER3 upregulation resulted with a better clinical outcome [17]. Seven core clock genes including CLOCK, BMAL1, PER1, PER2, PER3, CRY1, CRY2 were shown to be downregulated in colorectal liver metastases and lower mRNA levels of PER3 were associated with the increased number of metastases [4]. The altered mRNA levels of several circadian genes were reported in breast tumor samples compared to the non-tumor samples; while CLOCK and
TIMELESS genes were upregulated, PER1, PER2, PER3, and CRY2 were downregulated [18]. In a very recent study, significantly low mRNA expression levels of Per1, Per2, and Per3 were reported in locally advanced head and neck squamous cell carcinoma compared with early-stage cancer patients [6].

The above studies emphasize the importance of the altered expression patterns of circadian genes in tumorigenesis. Though not related to bladder cancer, there are also a limited number of cancer studies proving that circadian gene variants can also drive tumorigenesis. Firstly in 2005, it was shown that 5repeat alleles of PER3 VNTR were associated with an increased breast cancer risk among premenopausal women [19]. The first evidence related to the circadian gene hypothesis was then proposed in prostate tumorigenesis; CRY2-variant C allele was associated with increased prostate cancer risk and NPAS2-variant A allele was associated with decreased risk [20]. A single functional SNP of PER3 (rs2640908) was reported to be significantly associated with the overall survival of hepatocellular carcinoma patients [21]. Though PER3 VNTR was not associated with colorectal cancer susceptibility, an other circadian gene variant (CLOCK 311T >C) was proposed to be a risk factor in tumor development [22]. Four SNPs (rs3027178 in PER1, rs228669, and rs2640908 in PER3 and rs3809236 in CRY1) were reported to be significantly associated with overall survival of hepatocellular carcinoma patients, and three SNPs (rs3027178 in PER1, rs228729 in PER3 and rs3809236 in CRY1) were reported to be associated with recurrence-free survival [23]. Circadian gene variations in CCRN4L (rs3805213) and PER3 (rs228729) were risk factors in the occurrence and development of non-small cell lung cancer in Brazilian patients [24]. A PER1 variant (rs2289591) was reported to be associated with overall glioma risk [25]. CRY1 (rs1056560), PER1 (rs3027178) and PER3 (rs228729) were proposed as the predictors of the prognosis of gastric cancer patients [26]. PER3 rs10462020 variant was reported to be associated with overall survival in diffuse large B-cell lymphoma in the Mexican population [27]. PER3 5-repeat genotype was proposed as a risk factor in colorectal adenoma formation in contrast to our bladder carcinoma study [28]. Very recently, PER3 VNTR genotypes were evaluated in terms of radiotherapy time in breast cancer patients and revealed that 4/4 PER3 VNTR was associated with increased toxicity if treated in the morning compared with the afternoon [29]. These recapitulated studies on circadian genes variations would be quite beneficial in the future to improve the life quality of cancer patients and predict treatment regimens.

\section{Conclusion}

To the best of our knowledge, our study is the first evaluating the effect of PER3 VNTR in terms of both creating susceptibility to bladder carcinoma and also making risk assessment for overall survival. Disruption 
of circadian rhythms with various factors such as shift work, sleep times (morning/evening) and light exposure is a novel modifiable risk factor in cancer. These dysregulations on circadian rhythms alter the expression of PER/CLOCK circadian genes and the cellular processes these genes regulate. Variations in circadian genes influence sleep regulation and can thus contribute to cancer susceptibility based on sleep deprivation. Circadian genes have also immunomodulatory and tumor suppressor properties that render them an ideal candidate for future comprehensive studies in cancer. PER3 variable number tandem repeat (VNTR; rs57875989) length polymorphism contains 4 or 5 copies of a 54-bp sequence encoding 18 amino acids and thus carries a remarkable potential both to affect circadian gene expression alone or its interaction with other circadian genes and manages some hormonal secretion differences in melatonin and cortisol levels. Our study has several limitations. Firstly, our cohort may not be large enough to detect minimal associations. The log rank test can be applied to compare the survival times of patients in two or more groups, but it does not take the impacts of other predictors on the outcome into account. The cox proportion hazard model can be used to test the effects of recurrence, progression and cystectomy status (and the other predictors) on the survival times of patients simultaneously. However, the cox proportion hazard model containing these predictors must be a two-stage model considering both the survival times of patients and their status (i.e., alive or death). Our data contain categorical predictors and limited number of events (deaths) in PER3 VNTR groups. Thus, the cox proportion hazard model containing these variables does not have enough power to detect the significant effects of the variables on the survival times of patients. Secondly, the important clinical finding restricted to the Turkish cohort is definitely needed to be warranted in other larger populations and ethnicities. Based on our results, although PER3 VNTR genotypes do not have a direct influence on living status and survival times of the patients, their association with recurrence, progression and radical cystectomy play an important role to explain the underlying phenomenon. These variables have significant effects on the status of patients for PER3 VNTR with the genotypes $4 / 4$ and $4 / 5$. The survival times of patients are influenced by the levels of these variables for PER3 VNTR with the genotype 4/5 based on the log rank test results. However, only the variables progression and radical cystectomy, but not variable recurrence, have significant effects on the survival times of patients for PER3 VNTR with the genotype 4/4. In conclusion, our study presents the first evidence supporting the role of PER3 VNTR (rs57875989) in prediction of risk assessment of bladder carcinoma patients. As long as this hypothesis is also enlighted and validated in other populations with larger cohorts, individualized tailor-made clinical preventions could be planned in the future such as evaluation of PER3 VNTR genotypes in patients and deciding about more stringent treatment regimens and/or more frequent follow-up studies for individuals with certain genotypes.

\section{References}

[1] Chen, ST., Choo, KB., Hou, MF., Yeh, KT., Kuo, SJ., Chang, JG., "Deregulated expression of the PER1, PER2 and PER3 genes in breast cancers", Carcinogenesis, 26(7),1241-6, 2005.

[2] Lin, YM., Chang, JH., Yeh, KT., Yang, MY., Liu, TC., Lin, SF., Su, WW., Chang, JG., "Disturbance of circadian gene expression in hepatocellular carcinoma", Mol Carcinog, 47(12),925-33, 2008.

[3] Mazzoccoli, G., Panza, A., Valvano, MR., Palumbo, O., Carella, M., Pazienza, V., Biscaglia, G., Tavano, F., Di Sebastiano, P., Andriulli, A., Piepoli, A., "Clock gene expression levels and relationship with clinical and pathological features in colorectal cancer patients", Chronobiol Int, 28(10),841-51, 2011.

[4] Huisman, SA., Ahmadi, AR., IJzermans, JN., Verhoef, C., van der Horst, GT., de Bruin, RW., "Disruption of clock gene expression in human colorectal liver metastases", Tumour Biol, 37(10),13973-13981, 2016.

[5] Liu, B., Xu, K., Jiang, Y., Li, X., "Aberrant expression of Per1, Per2 and Per3 and their prognostic relevance in non-small cell lung cancer", Int J Clin Exp Pathol, 7(11),7863-71, 2014.

[6] Li, YY., Jin, F., Zhou, JJ., Yu, F., Duan, XF., He, XY., Wang, R., Wu, WL., Long, JH., Luo, XL., "Downregulation of the circadian Period family genes is positively correlated with poor head and neck squamous cell carcinoma prognosis", Chronobiol Int, 36(12),17231732, 2019.

[7] Bass, J., Takahashi, JS., "Circadian integration of metabolism and energetics", Science, 330(6009),134954, 2010.

[8] Dijk, DJ., Archer, SN., "PERIOD3, circadian phenotypes, and sleep homeostasis", Sleep Med Rev, 14(3),151-60, 2010.

[9] Benedetti, F., Dallaspezia, S., Colombo, C., Pirovano, A., Marino, E., Smeraldi, E., "A length polymorphism in the circadian clock gene Per3 influences age at onset of bipolar disorder", Neurosci Lett, 445(2),184-7, 2008.

[10] Guess, J., Burch, JB., Ogoussan, K., Armstead, CA., Zhang, H., Wagner, S., Hebert, JR., Wood, P., Youngstedt, SD., Hofseth, LJ., Singh, UP., Xie, D., Hrushesky, WJ., "Circadian disruption, Per3, and human cytokine secretion", Integr Cancer Ther, 8(4),329-36, 2009. 
[11] Miller, SA., Dykes, DD., Polesky, HF., "A simple salting out procedure for extracting DNA from human nucleated cells", Nucleic Acids Res, 16(3),1215, 1988.

[12] Fu, L., Pelicano, H., Liu, J., Huang, P., Lee, C., “The circadian gene Period2 plays an important role in tumor suppression and DNA damage response in vivo", Cell, 111(1),41-50, 2002.

[13] Yang, MY., Chang, JG., Lin, PM., Tang, KP., Chen, YH., Lin, HY., Liu, TC., Hsiao, HH., Liu, YC., Lin, SF., "Downregulation of circadian clock genes in chronic myeloid leukemia: alternative methylation pattern of hPER3", Cancer Sci, 97(12),1298-307, 2006.

[14] Oshima, T., Takenoshita, S., Akaike, M., Kunisaki, C., Fujii, S., Nozaki, A., Numata, K., Shiozawa, M., Rino, Y., Tanaka, K., Masuda, M., Imada, T., "Expression of circadian genes correlates with liver metastasis and outcomes in colorectal cancer", Oncol Rep, 25(5),143946, 2011.

[15] Wang, X., Yan, D., Teng, M., Fan, J., Zhou, C., Li, D., Qiu, G., Sun, X., Li, T., Xing, T., Tang, H., Peng, X., Peng, Z., "Reduced expression of PER3 is associated with incidence and development of colon cancer", Ann Surg Oncol, 19(9),3081-8, 2012.

[16] Relles, D., Sendecki, J., Chipitsyna, G., Hyslop, T., Yeo, CJ., Arafat, HA., "Circadian gene expression and clinicopathologic correlates in pancreatic cancer", $J$ Gastrointest Surg, 17(3),443-50, 2013.

[17] Yang, MY., Lin, PM., Hsiao, HH., Hsu, JF., Lin, HY., Hsu, CM., Chen, IY., Su, SW., Liu, YC., Lin, SF., “Upregulation of PER3 Expression Is Correlated with Better Clinical Outcome in Acute Leukemia", Anticancer Res, 35(12),6615-22, 2015.

[18] Lesicka, M., Jabłońska, E., Wieczorek, E., Seroczyńska, B., Siekierzycka, A., Skokowski, J., Kalinowski, L., Wąsowicz, W., Reszka, E., "Altered circadian genes expression in breast cancer tissue according to the clinical characteristics", PLoS One, 13(6),e0199622, 2018.

[19] Zhu, Y., Brown, HN., Zhang, Y., Stevens, RG., Zheng, T., "Period3 structural variation: a circadian biomarker associated with breast cancer in young women", Cancer Epidemiol Biomarkers Prev, 14(1),268-70, 2005.

[20] Chu, LW., Zhu, Y., Yu, K., Zheng, T., Yu, H., Zhang, Y., Sesterhenn, I., Chokkalingam, AP., Danforth, KN., Shen, MC., Stanczyk, FZ., Gao, YT., Hsing, AW., "Variants in circadian genes and prostate cancer risk: a populationbased study in China", Prostate Cancer Prostatic Dis, 11(4),342-8, 2008.
[21] Zhao, B., Lu, J., Yin, J., Liu, H., Guo, X., Yang, Y., Ge, N., Zhu, Y., Zhang, H., Xing, J., "A functional polymorphism in PER3 gene is associated with prognosis in hepatocellular carcinoma", Liver Int, 32(9),1451-9, 2012.

[22] Karantanos, T., Theodoropoulos, G., Gazouli, M., Vaiopoulou, A., Karantanou, C., Stravopodis, DJ., Bramis, K., Lymperi, M., Pektasidis, D., "Association of the clock genes polymorphisms with colorectal cancer susceptibility", J Surg Oncol, 108(8),563-7, 2013.

[23] Zhang, Z., Ma, F., Zhou, F., Chen, Y., Wang, X., Zhang, H., Zhu, Y., Bi, J., Zhang, Y., "Functional polymorphisms of circadian negative feedback regulation genes are associated with clinical outcome in hepatocellular carcinoma patients receiving radical resection", Med Oncol, 31(12),179, 2014.

[24] Couto, P., Miranda, D., Vieira, R., Vilhena, A., De Marco, L., Bastos-Rodrigues, L., "Association between CLOCK, PER3 and CCRN4L with non-small cell lung cancer in Brazilian patients", Mol Med Rep, 10(1),435$40,2014$.

[25] Madden, MH., Anic, GM., Thompson, RC., Nabors, LB., Olson, JJ., Browning, JE., Monteiro, AN., Egan, KM., "Circadian pathway genes in relation to glioma risk and outcome”, Cancer Causes Control, 25(1),25-32, 2014.

[26] Qu, F., Qiao, Q., Wang, N., Ji, G., Zhao, H., He, L., Wang, H., Bao, G., "Genetic polymorphisms in circadian negative feedback regulation genes predict overall survival and response to chemotherapy in gastric cancer patients", Sci Rep, 6,22424, 2016.

[27] Gutiérrez-Monreal, MA., Villela, L., Baltazar, S., Perfecto-Avalos, Y., Cardineau, GA., Scott, SP., "A PER3 polymorphism is associated with better overall survival in diffuse large B-cell lymphoma in Mexican population", Cancer Biomark, 15(5),699-705, 2015.

[28] Alexander, M., Burch, JB., Steck, SE., Chen, CF., Hurley, TG., Cavicchia, P., Ray, M., Shivappa, N., Guess, J., Zhang, H,, Youngstedt, SD., Creek, KE., Lloyd, S., Yang, X., Hébert, JR., "Case-control study of the PERIOD3 clock gene length polymorphism and colorectal adenoma formation", Oncol Rep, 33(2),935-41, 2015.

[29] Johnson, K., Chang-Claude, J., Critchley, AM., Kyriacou, C., Lavers, S., Rattay, T., Seibold, P., Webb, A., West, C., Symonds, RP., Talbot, CJ., "Genetic Variants Predict Optimal Timing of Radiotherapy to Reduce Sideeffects in Breast Cancer Patients", Clin Oncol ( $R$ Coll Radiol), 31(1),9-16, 2019. 
Table 1. Frequencies (n) and percentages (\%) of bladder cancer patients in terms of their demographic and clinicopathologic characteristics for PER3 VNTR with 4/4, 4/5 and 5/5 genotypes (and all patients together)

\begin{tabular}{|c|c|c|c|c|c|c|c|c|}
\hline \multirow[b]{2}{*}{ Variables } & \multicolumn{2}{|c|}{ 4/4 genotype $n(\%)$} & \multicolumn{2}{|c|}{ 4/5 genotype $n(\%)$} & \multicolumn{2}{|c|}{$5 / 5$ genotype $n(\%)$} & \multicolumn{2}{|c|}{ Total n(\%) } \\
\hline & Death & Alive & Death & Alive & Death & Alive & Death & Alive \\
\hline \multicolumn{9}{|l|}{ Age } \\
\hline$<60$ & $0(0 \%)$ & $10(24 \%)$ & $0(0 \%)$ & $13(22 \%)$ & $0(0 \%)$ & $2(14 \%)$ & $0(0 \%)$ & $25(21 \%)$ \\
\hline$\geq 60$ & $3(7 \%)$ & $29(69 \%)$ & $5(8 \%)$ & $42(70 \%)$ & $1(7 \%)$ & $11(79 \%)$ & $9(8 \%)$ & $82(71 \%)$ \\
\hline \multicolumn{9}{|l|}{ Gender } \\
\hline Female & $0(0 \%)$ & $9(21 \%)$ & $0(0 \%)$ & $8(13 \%)$ & $0(0 \%)$ & $4(28 \%)$ & $0(0 \%)$ & $21(18 \%)$ \\
\hline Male & $3(7 \%)$ & $30(72 \%)$ & $5(8 \%)$ & $47(79 \%)$ & $1(7 \%)$ & $9(65 \%)$ & $9(8 \%)$ & $86(74 \%)$ \\
\hline \multicolumn{9}{|l|}{ Smoking } \\
\hline No & $1(3 \%)$ & $6(12 \%)$ & $0(0 \%)$ & $9(15 \%)$ & $0(0 \%)$ & $2(14 \%)$ & $1(\% 1)$ & $17(15 \%)$ \\
\hline Yes & $2(6 \%)$ & $33(79 \%)$ & $5(8 \%)$ & $46(77 \%)$ & $1(7 \%)$ & $11(79 \%)$ & $8(7 \%)$ & $90(77 \%)$ \\
\hline \multicolumn{9}{|l|}{ Tumor type } \\
\hline pTa/LMPUN & $1(2 \%)$ & $14(33 \%)$ & $0(0 \%)$ & $25(42 \%)$ & $0(0 \%)$ & $8(57 \%)$ & $1(1 \%)$ & $47(40 \%)$ \\
\hline pT1/pT2 & $2(5 \%)$ & $25(60 \%)$ & $5(8 \%)$ & $30(50 \%)$ & $1(7 \%)$ & $5(36 \%)$ & $8(7 \%)$ & $60(52 \%)$ \\
\hline \multicolumn{9}{|l|}{ Grade } \\
\hline Low & $0(0 \%)$ & $27(64 \%)$ & $2(3 \%)$ & $40(67 \%)$ & $1(7 \%)$ & $11(79 \%)$ & $3(3 \%)$ & $78(67 \%)$ \\
\hline High & $3(7 \%)$ & $12(29 \%)$ & $3(5 \%)$ & $15(25 \%)$ & $0(0 \%)$ & $2(14 \%)$ & $6(5 \%)$ & $29(25 \%)$ \\
\hline \multicolumn{9}{|l|}{ Associated CIS } \\
\hline No & $3(7 \%)$ & 38 (91\%) & $5(8 \%)$ & $52(87 \%)$ & $1(7 \%)$ & $13(93 \%)$ & $9(7 \%)$ & $103(86 \%)$ \\
\hline Yes & $0(0 \%)$ & $1(2 \%)$ & $0(0 \%)$ & $3(5 \%)$ & $0(0 \%)$ & $0(0 \%)$ & $0(0 \%)$ & $9(7 \%)$ \\
\hline \multicolumn{9}{|l|}{ Tumor size } \\
\hline$<3$ & $3(7 \%)$ & $26(62 \%)$ & $2(3 \%)$ & $39(65 \%)$ & $0(0 \%)$ & $10(71 \%)$ & $5(4 \%)$ & $75(65 \%)$ \\
\hline$\geq 3$ & $0(0 \%)$ & $13(31 \%)$ & $3(5 \%)$ & $16(27 \%)$ & $1(7 \%)$ & $3(22 \%)$ & $4(3 \%)$ & $32(28 \%)$ \\
\hline \multicolumn{9}{|l|}{ Tumor number } \\
\hline Single & $3(7 \%)$ & $26(62 \%)$ & $2(3 \%)$ & $39(65 \%)$ & $0(0 \%)$ & $10(72 \%)$ & $5(4 \%)$ & $75(65 \%)$ \\
\hline Multiple & $0(0 \%)$ & $13(31 \%)$ & $3(5 \%)$ & $16(27 \%)$ & $1(7 \%)$ & $3(21 \%)$ & $4(3 \%)$ & $32(28 \%)$ \\
\hline \multicolumn{9}{|l|}{ Recurrence } \\
\hline No & $0(0 \%)$ & $31(74 \%)$ & $0(0 \%)$ & $5(8 \%)$ & $0(0 \%)$ & $10(72 \%)$ & $0(0 \%)$ & $79(68 \%)$ \\
\hline Yes & $3(7 \%)$ & $8(19 \%)$ & 38 (64\%) & $17(28 \%)$ & $1(7 \%)$ & $3(21 \%)$ & $9(8 \%)$ & $28(24 \%)$ \\
\hline \multicolumn{9}{|l|}{ Progression } \\
\hline No & $0(0 \%)$ & 37 (88\%) & $0(0 \%)$ & $50(84 \%)$ & $0(0 \%)$ & $12(86 \%)$ & $0(0 \%)$ & 99 (85\%) \\
\hline Yes & $3(7 \%)$ & $2(5 \%)$ & $5(8 \%)$ & $5(8 \%)$ & $1(7 \%)$ & $1(7 \%)$ & $9(8 \%)$ & $8(7 \%)$ \\
\hline \multicolumn{9}{|c|}{ Radical cystectomy } \\
\hline No & $1(2 \%)$ & $36(86 \%)$ & $1(2 \%)$ & $48(80 \%)$ & $1(7 \%)$ & $13(93 \%)$ & $3(3 \%)$ & $97(84 \%)$ \\
\hline \multirow[t]{2}{*}{ Yes } & $2(5 \%)$ & $3(7 \%)$ & $4(6 \%)$ & $7(12 \%)$ & $0(0 \%)$ & $0(0 \%)$ & $6(5 \%)$ & $10(8 \%)$ \\
\hline & \multicolumn{2}{|c|}{$\begin{array}{l}\text { 4/4 genotype } \\
\text { Median } \\
\text { (interquartile) }\end{array}$} & \multicolumn{2}{|c|}{$\begin{array}{l}\text { 4/5 genotype } \\
\text { Median } \\
\text { (interquartile) }\end{array}$} & \multicolumn{2}{|c|}{$\begin{array}{l}\text { 5/5 genotype } \\
\text { Median } \\
\text { (interquartile) }\end{array}$} & \multicolumn{2}{|c|}{$\begin{array}{c}\text { Total } \\
\text { Median } \\
\text { (interquartile) }\end{array}$} \\
\hline Survival times & $62(33.5)$ & $84(46)$ & $73(36)$ & $45(12)$ & $66(46)$ & $160(0)$ & $69(43)$ & $49(39)$ \\
\hline
\end{tabular}


Table 2. The relationship between PER3 VNTR and bladder cancer

\begin{tabular}{lccccccc}
\hline \multicolumn{7}{c}{ Controls } & \multicolumn{1}{c}{ Patients } \\
\hline Genotype & $\mathrm{n}$ & $\%$ & $\mathrm{n}$ & $\%$ & $\chi^{2}$ & $\mathrm{p}$-value & OR (95\% CI) \\
$\mathbf{4 / 4}$ & 54 & 0.45 & 42 & 0.36 & & & \\
$\mathbf{4 / 5}$ & 47 & 0.39 & 60 & 0.52 & 2.601 & 0.107 & $1.637[0.9082 .971]$ \\
$\mathbf{5 / 5}$ & 19 & 0.16 & 14 & 0.12 & 0.000 & 1.000 & $0.948[0.3902 .262]$ \\
$\mathbf{4 - r e p e a t s ~ a l l e l e ~ f r e q u e n c y ~}$ & 155 & 0.65 & 144 & 0.62 & & & \\
\hline $\mathbf{5 - r e p e a t s ~ a l l e l e ~ f r e q u e n c y ~}$ & 85 & 0.35 & 88 & 0.38 & 0.222 & 0.638 & $1.114[0.7531 .649]$ \\
\hline
\end{tabular}


Table 3. Association between the status of patients and the levels of demographic and clinicopathologic variables for PER3 VNTR with the $4 / 4,4 / 5$ and 5/5 genotypes (and all patients together)

\begin{tabular}{|c|c|c|c|c|c|c|c|c|}
\hline \multirow{2}{*}{ Variables } & \multicolumn{2}{|c|}{ 4/4 genotype } & \multicolumn{2}{|c|}{ 4/5 genotype } & \multicolumn{2}{|c|}{ 5/5 genotype } & \multicolumn{2}{|l|}{ Total } \\
\hline & $\chi^{2}$ & $\mathrm{p}$ & $\chi^{2}$ & $\mathrm{p}$ & $\chi^{2}$ & $\mathrm{p}$ & $\chi^{2}$ & $\mathrm{p}$ \\
\hline \multicolumn{9}{|l|}{ Age } \\
\hline \multicolumn{9}{|l|}{$<60$} \\
\hline$\geq 60$ & 0.091 & 0.763 & 0.437 & 0.508 & 0.000 & 1.000 & 1.477 & 0.224 \\
\hline \multicolumn{9}{|l|}{ Gender } \\
\hline \multicolumn{9}{|l|}{ Female } \\
\hline Male & 0.044 & 0.835 & 0.052 & 0.819 & 0.000 & 1.000 & 1.036 & 0.309 \\
\hline \multicolumn{9}{|l|}{ Smoking } \\
\hline \multicolumn{9}{|l|}{ No } \\
\hline Yes & 0.000 & 1.000 & 0.107 & 0.744 & 0.000 & 1.000 & 0.000 & 1.000 \\
\hline \multicolumn{9}{|c|}{ Tumor type } \\
\hline \multicolumn{9}{|c|}{ pTa/LMPUN } \\
\hline $\mathrm{pT} 1 / \mathrm{pT} 2$ & 0.000 & 1.000 & 2.250 & 0.134 & 0.022 & 0.881 & 2.457 & 0.117 \\
\hline \multicolumn{9}{|l|}{ Grade } \\
\hline \multicolumn{9}{|l|}{ Low } \\
\hline High & 3.191 & 0.074 & 1.039 & 0.308 & 0.000 & 1.000 & 4.433 & 0.035 \\
\hline \multicolumn{9}{|c|}{ Associated CIS } \\
\hline \multicolumn{9}{|l|}{ No } \\
\hline Yes & 0.000 & 1.000 & 0.000 & 1.000 & -- & -- & 0.000 & 1.000 \\
\hline \multicolumn{9}{|l|}{ Tumor size } \\
\hline \multicolumn{9}{|l|}{$<3$} \\
\hline$\geq 3$ & 0.309 & 0.579 & 0.847 & 0.357 & 0.242 & 0.623 & 0.281 & 0.596 \\
\hline \multicolumn{9}{|c|}{ Tumor number } \\
\hline \multicolumn{9}{|l|}{ Single } \\
\hline Multiple & 0.309 & 0.579 & 0.847 & 0.357 & 0.242 & 0.623 & 0.281 & 0.596 \\
\hline \multicolumn{9}{|c|}{ Recurrence } \\
\hline \multicolumn{9}{|l|}{ No } \\
\hline Yes & 5.457 & 0.019 & 6.681 & 0.010 & 0.242 & 0.623 & 17.572 & 0.000 \\
\hline \multicolumn{9}{|c|}{ Progression } \\
\hline \multicolumn{9}{|l|}{ No } \\
\hline Yes & 15.717 & 0.000 & 21.120 & 0.000 & 1.122 & 0.290 & 49.664 & 0.000 \\
\hline \multicolumn{9}{|c|}{ Radical cystectomy } \\
\hline \multicolumn{9}{|l|}{ No } \\
\hline Yes & 4.471 & 0.034 & 9.725 & 0.002 & -- & -- & 18.372 & 0.000 \\
\hline
\end{tabular}


Table 4. Association between the survival times of patients and the levels of demographic and clinicopathologic variables for PER3 VNTR with the 4/4, $4 / 5$ and $5 / 5$ genotypes (and all patients together)

\begin{tabular}{|c|c|c|c|c|c|c|c|c|}
\hline \multirow{2}{*}{ Variables } & \multicolumn{2}{|c|}{ 4/4 genotype } & \multicolumn{2}{|c|}{ 4/5 genotype } & \multicolumn{2}{|c|}{$5 / 5$ genotype } & \multicolumn{2}{|l|}{ Total } \\
\hline & $\chi^{2}$ & $\mathrm{p}$ & $\chi^{2}$ & $\mathrm{p}$ & $\chi^{2}$ & $\mathrm{p}$ & $\chi^{2}$ & $\mathrm{p}$ \\
\hline \multicolumn{9}{|l|}{ Age } \\
\hline \multicolumn{9}{|l|}{$<60$} \\
\hline$\geq 60$ & 0.828 & 0.363 & 1.434 & 0.231 & 0.000 & 1.000 & 3.000 & 0.083 \\
\hline \multicolumn{9}{|l|}{ Gender } \\
\hline \multicolumn{9}{|l|}{ Female } \\
\hline Male & 0.278 & 0.598 & 0.770 & 0.380 & 0.500 & 0.480 & 1.787 & 0.181 \\
\hline \multicolumn{9}{|l|}{ Smoking } \\
\hline \multicolumn{9}{|l|}{ No } \\
\hline Yes & 1.045 & 0.307 & 0.944 & 0.331 & 0.500 & 0.480 & 0.206 & 0.650 \\
\hline \multicolumn{9}{|c|}{ Tumor type } \\
\hline \multicolumn{9}{|c|}{ pTa/LMPUN } \\
\hline $\mathrm{pT} 1 / \mathrm{pT} 2$ & 0.413 & 0.520 & 3.520 & 0.061 & 2.000 & 0.157 & 2.693 & 0.101 \\
\hline \multicolumn{9}{|l|}{ Grade } \\
\hline \multicolumn{9}{|l|}{ Low } \\
\hline High & 3.162 & 0.075 & 2.162 & 0.141 & 0.000 & 1.000 & 5.813 & 0.016 \\
\hline \multicolumn{9}{|c|}{ Associated CIS } \\
\hline \multicolumn{9}{|l|}{ No } \\
\hline Yes & 0.000 & 1.000 & 0.287 & 0.592 & -- & -- & 0.563 & 0.453 \\
\hline \multicolumn{9}{|c|}{ Tumor size } \\
\hline \multicolumn{9}{|l|}{$<3$} \\
\hline$\geq 3$ & 2.019 & 0.155 & 1.988 & 0.159 & 2.000 & 0.157 & 0.625 & 0.429 \\
\hline \multicolumn{9}{|c|}{ Tumor number } \\
\hline \multicolumn{9}{|l|}{ Single } \\
\hline Multiple & 2.019 & 0.155 & 1.988 & 0.159 & 2.000 & 0.157 & 0.625 & 0.429 \\
\hline \multicolumn{9}{|c|}{ Recurrence } \\
\hline \multicolumn{9}{|l|}{ No } \\
\hline Yes & 0.167 & 0.280 & 8.891 & 0.003 & 0.000 & 1.000 & 10.982 & 0.001 \\
\hline \multicolumn{9}{|c|}{ Progression } \\
\hline \multicolumn{9}{|l|}{ No } \\
\hline Yes & 5.271 & 0.022 & 30.057 & 0.000 & 0.500 & 0.480 & 41.443 & 0.000 \\
\hline \multicolumn{9}{|c|}{ Radical cystectomy } \\
\hline \multicolumn{9}{|l|}{ No } \\
\hline Yes & 7.658 & 0.006 & 15.142 & 0.000 & -- & -- & 10.084 & 0.000 \\
\hline
\end{tabular}




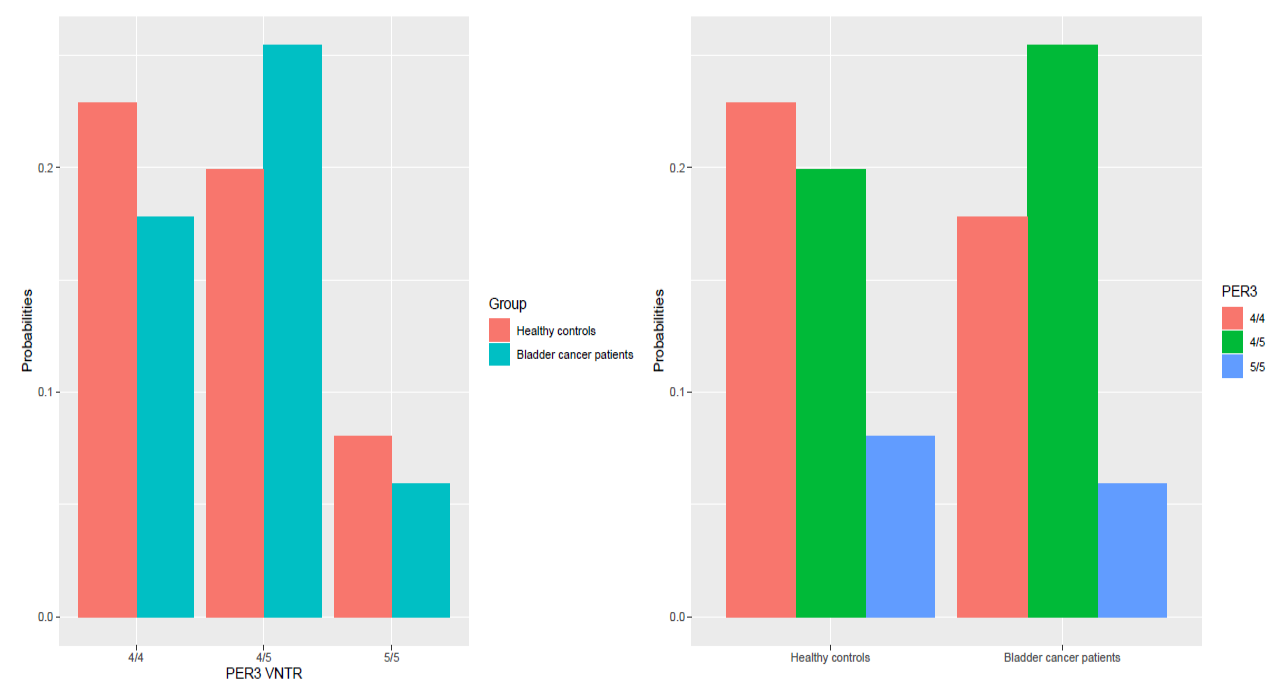

Figure 1. The box plots comparing the probabilities between the levels of groups (i.e., controls and patients) and the levels of PER3 VNTR (i.e., the genotypes $4 / 4,4 / 5$ and 5/5) 

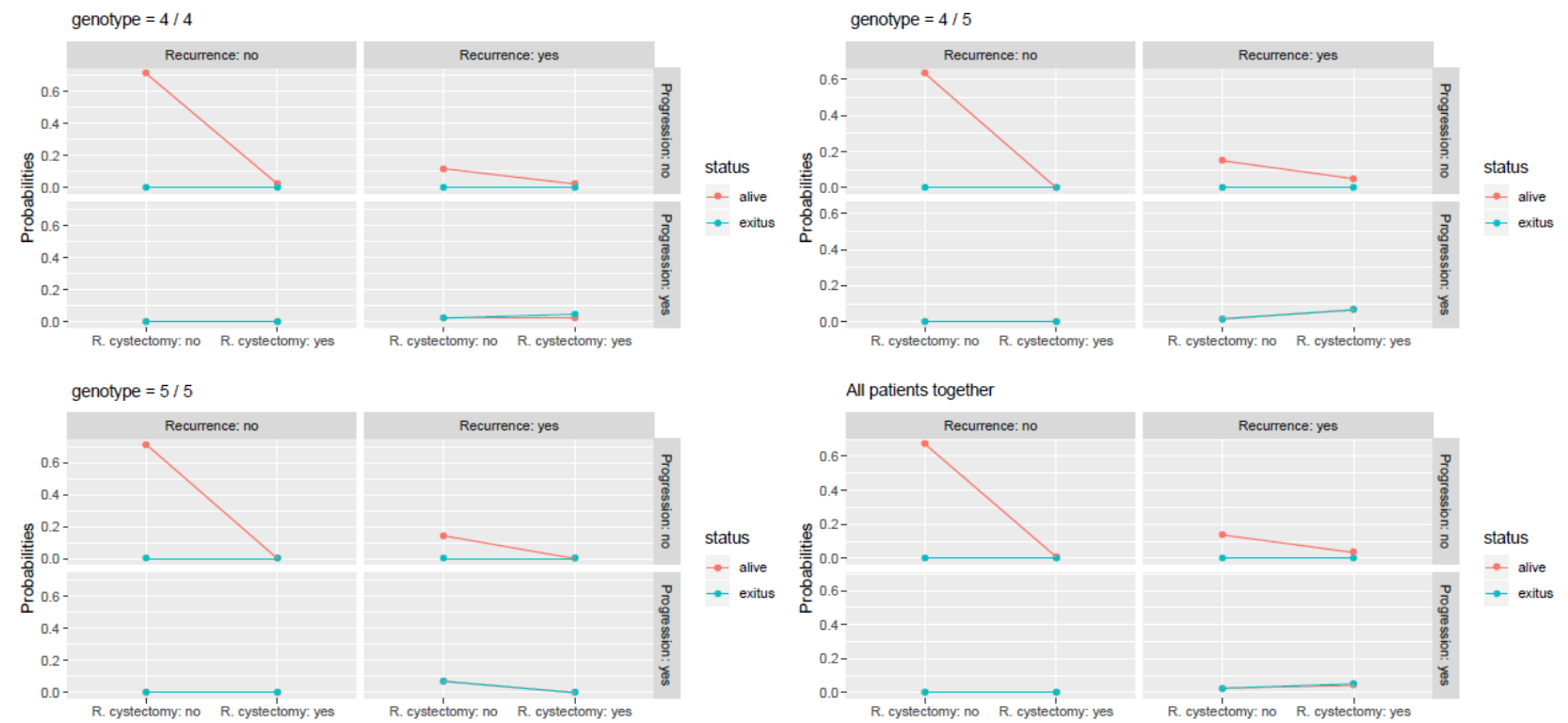

Figure 2. The interaction plots between the status of patients and the levels recurrence, progression and radical cystectomy 


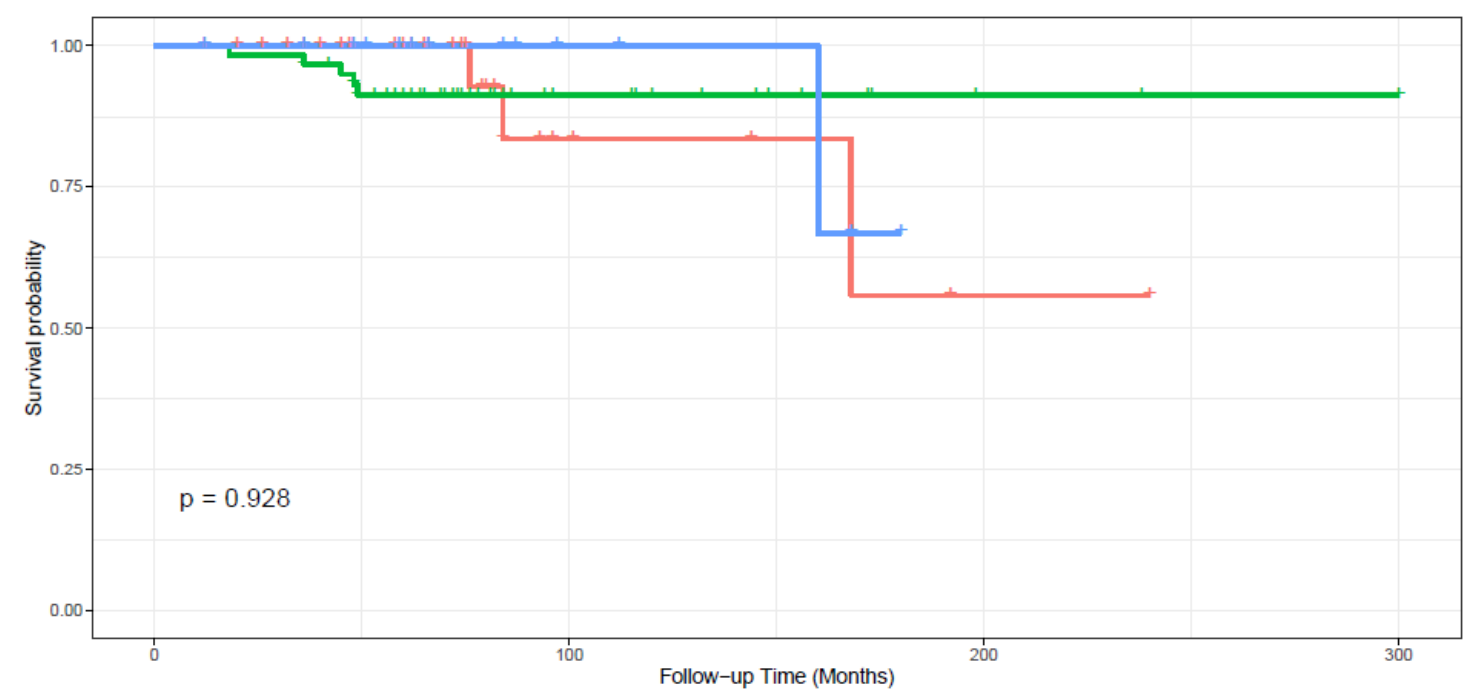

Patients at risk

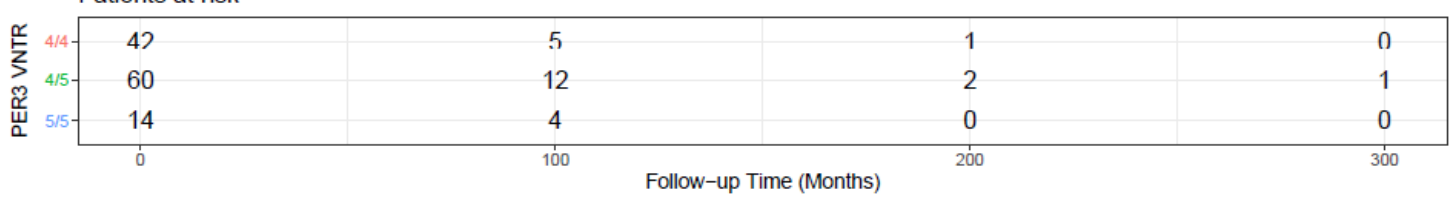

Figure 3. The survival curves for the levels of PER3 VNTR 

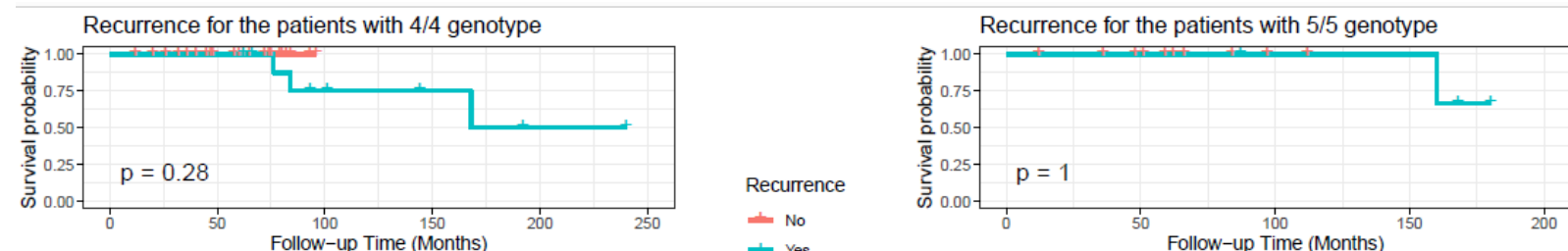

Recurrence

\pm No
\pm Yes

- No
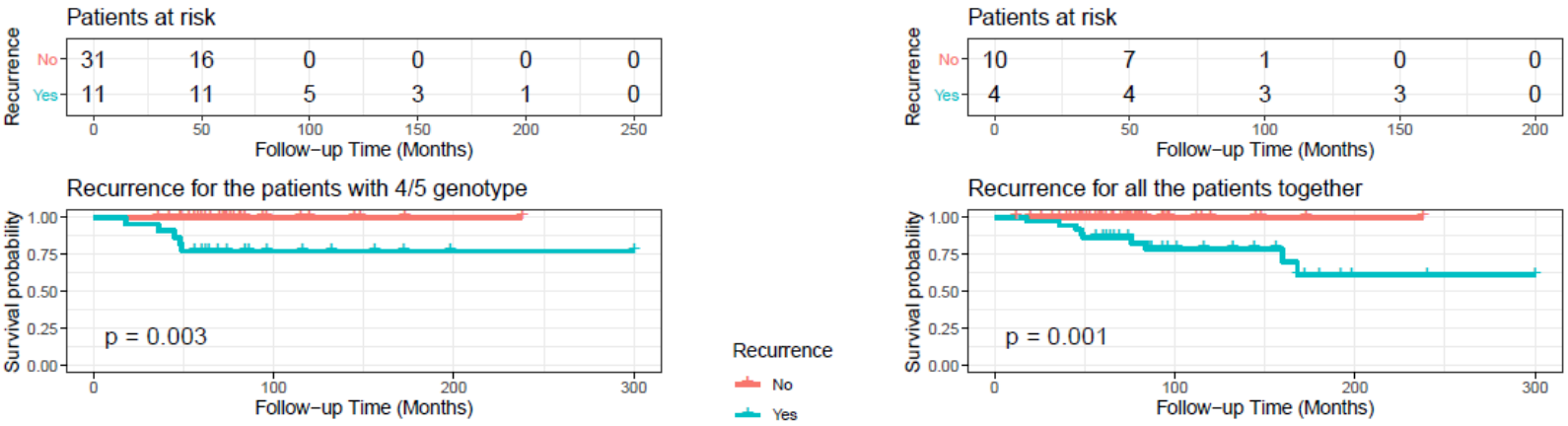

Recurrence

No

Follow-up Time (Months)

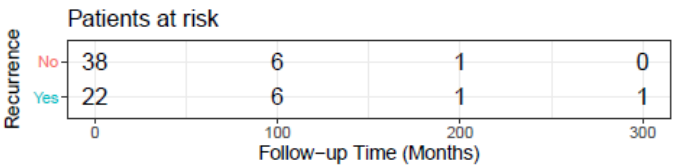

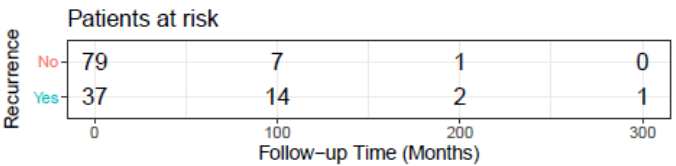

Figure 4. The survival curves for the levels of variable recurrence 


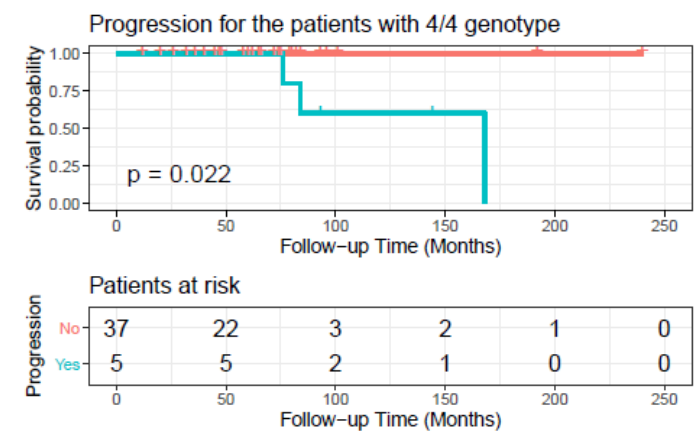

Progression for the patients with $4 / 5$ genotype
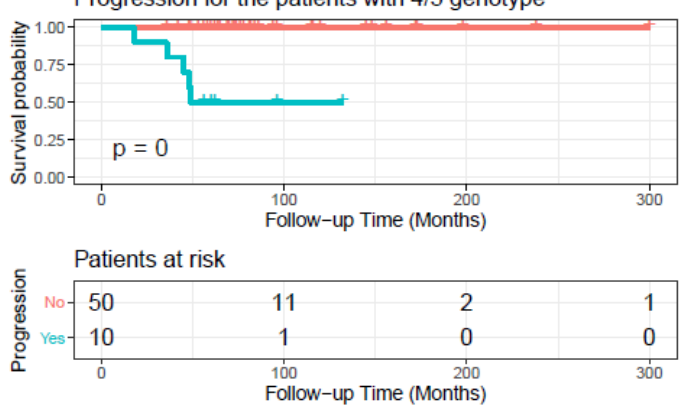
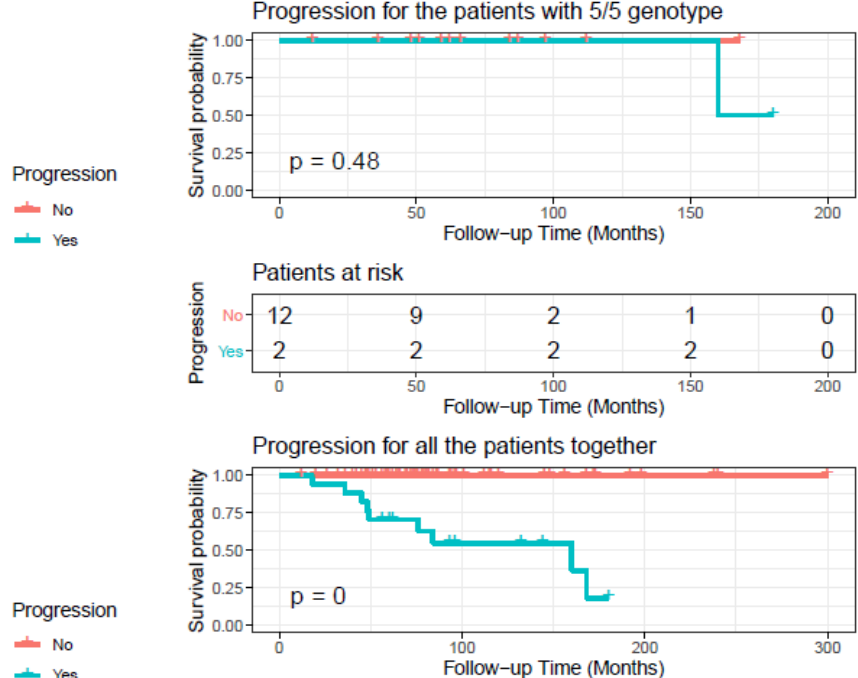

Progression

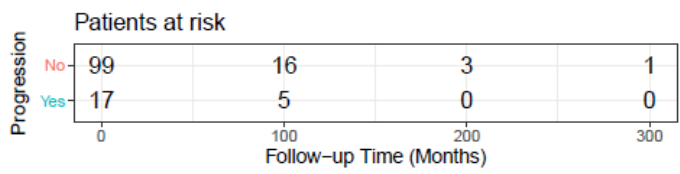

Figure 5. The survival curves for the levels of variable progression 

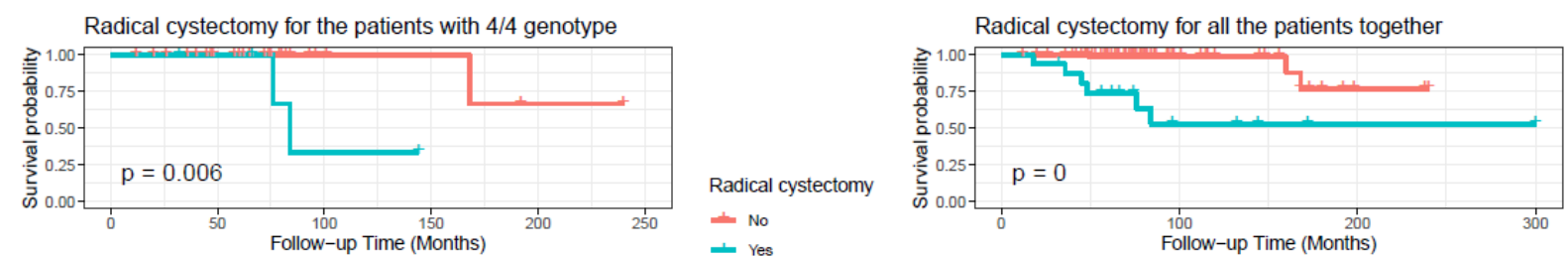

Radical cystectomy
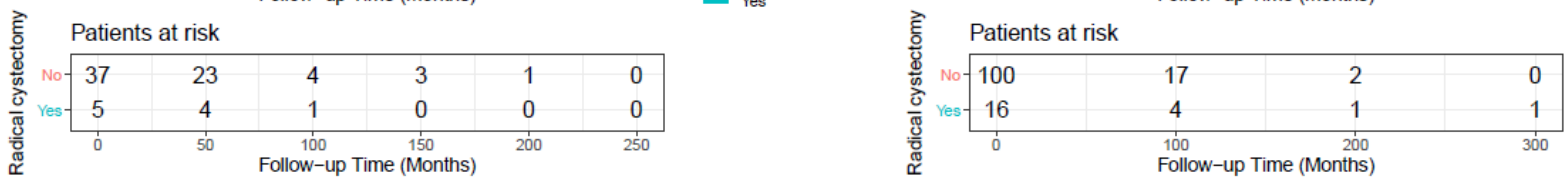